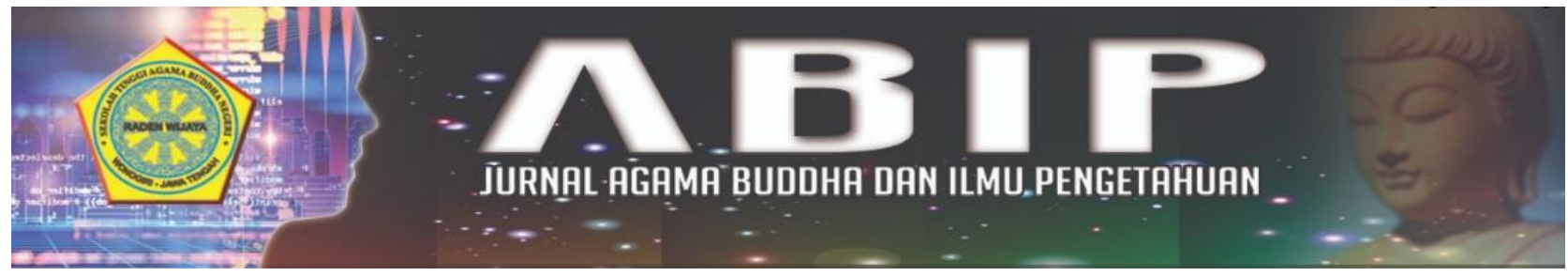

\title{
PERAN KEGIATAN CHILDREN DHAMMA PROGRAM (CDP) DALAM MEMBENTUK PERILAKU SOSIAL ANAK-ANAK BUDDHIS DI DUSUN LENEK, DS. BENTEK, KEC. GANGGA, KAB. LOMBOK UTARA
}

\author{
Sopiani \\ Sekolah Tinggi Agama Buddha Kertarajasa \\ sofianikhanticarini@gmail.com
}

\begin{abstract}
Abstrak
Penelitian ini mengkaji tentang kegiatan Children Dhamma Program (CDP) dalam membentuk perilaku sosial anak-anak Buddhis di Dusun Lenek, Ds. Bentek, Kec. Gangga, Kab. Lombok Utara. Latar belakang dari penelitian ini adalah setiap anak memiliki keingintahuan yang besar terhadap halhal yang baru, dengan kata lain lingkungan memiliki peran penting dalam pembentukan perilaku anak-anak. Oleh karena itu, Vihara Buddhavamsa mengadakan kegiatan Children Dhamma Program (CDP) untuk membentuk perilaku anak-anak Buddhis di Dusun Lenek yang dapat diterima dalam masyarakat. Metode penelitian yang digunakan adalah deskriptif kualitatif. Teknik pengumpulan data dalam penelitian ini diperoleh dari observasi, wawancara dan dokumentasi. Hasil penelitian menunjukan bahwa kegiatan tersebut cukup baik dalam membentuk perilaku sosial anak-anak Buddhis yang ada di Dusun Lenek.
\end{abstract}

Kata kunci: Children Dhamma Program (CDP), Perilaku Sosial

\begin{abstract}
This study examines the activities of the Children Dhamma Program (CDP) in building the social behavior of Buddhist children in Dusun Lenek, Ds. Bentek, Kec. Gangga, Kab. Lombok Utara. The background of this research is that every child has a great curiosity about new things, in other words the environment has an important role in building children's behavior. Therefore, Vihara Buddhavamsa held a Children Dhamma Program (CDP) activity to build the behavior of Buddhist children in Dusun Lenek that was acceptable in society. The research method used is descriptive qualitative. Data collection techniques in this study were obtained from observation, interviews and documentation. The results showed that the activity was quite good in building the social behavior of Buddhist children in Dusun Lenek.
\end{abstract}

Keywords: Children Dhamma Program (CDP), Social Behavior 


\section{PENDAHULUAN}

Setiap anak memiliki keinginan untuk mengetahui sesuatu yang dilakukan oleh orang lain. Hal tersebut menunjukan bahwa lingkungan berpengaruh terhadap pembentukan perilaku sosial anak. Lingkungan memegang peran penting, agar anak-anak tidak salah dan terjerumus kepada hal yang buruk dan perilaku yang tidak diterima lingkungan ketika beradaptasi di masyarakat. Pada saat anak-anak membangun hubungan dengan orang lain, maka anak-anak akan melewati peristiwa-peristiwa dalam kehidupannya. Peristiwa tersebut akan tertanam kuat dalam memori seiring berjalannya waktu.

Perilaku sosial berhubungan pada perilaku anak dalam menyesuaikan diri dengan aturan-aturan masyarakat di lingkungan sekitar. Kesuksesan dalam pembentukan perilaku sosial pada anak-anak tidak terlepas dari keterlibatan anggota keluarga, sekolah, dan lingkungan masyarakat di sekitar.

Perilaku sosial seseorang merupakan sifat relatif untuk menanggapi orang lain dengan cara-cara yang berbeda. Misalnya dalam kerjasama, ada orang yang melakukan dengan tekun, sabar dan selalu mementingkan kepentingan bersama diatas kepentingan pribadinya. Dalam pembentukan perilaku sosial anak-anak Vihara Buddhavamsa mengadakan kegiatan Childern Dhamma Program (CDP).

Children Dhamma Program (CDP) dilaksanakan dari tahun 2011-2020, kegiatan ini sudah berlangsung selama 10 tahun lamanya. Kegiatan ini dilaksanakan disalah satu Dusun yang ada di Pulau Lombok, yakni Lombok Utara tepatnya di Vihara Buddhavamsa Lenek. Kegiatan ini diadakan untuk anak-anak Buddhis yang ada di Lombok Utara. Kegiatan ini didukung oleh salah satu donatur yang berasal dari Jakarta Utara.

Children Dhamma Program (CDP) merupakan kegiatan meditasi untuk anakanak, tujuan dari kegiatan ini adalah untuk membimbing dan membina anak-anak agar mereka mampu memahami dan mengerti dengan benar Ajaran Buddha dengan pengertian benar. Kemudian, anak-anak dapat mempraktikannya dalam kehidupan seharihari, dan seiring dengan perjalanan waktu, diharapkan mereka beranjak dewasa meraka dapat membagi Dhamma dengan pemahaman yang benar kepada generasi selanjutnya.

Kegiatan ini mengajarkan anak-anak Buddhis yang ada di Dusun Lenek bagaimana cara merawat diri, melatih kesabaran, bagaimana cara berbicara dengan baik kepada orang yang lebih tua, mengajarkan bagaimana menjadi anak yang mandiri. Dalam kegiatan ini anak-anak diwajibkan untuk mengurus diri mereka sendiri tanpa ada bantuan dari orang lain. Namun, mereka juga dapat meminta bantuan kepada para Veyyavacca (volunteer/panitia) yang banyak dikenal sebagai Dhammawoker.

Perilaku sosial menunjukkan

kemampuan untuk menjadi orang yang bermasyarakat. Lebih lanjut lagi, perilaku sosial adalah istilah yang digunakan untuk menggambarkan perilaku umum yang ditunjukkan oleh individu dalam masyarakat, yang pada dasarnya sebagai respon terhadap apa yang dianggap dapat diterima atau tidak diterima oleh kelompok sebaya seseorang (Hurlock, 2003: 261)

Perilaku secara bahasa berarti cara berbuat atau menajalankan sesuatu sesuai dengan sifat yang layak bagi manusia. Secara sosial berarti segala sesuatu mengenai masyarakat atau kemasyarakatan. Sedangkan secara istilah diartikan sebagai: Perilaku sosial adalah aktivitas fisik dan psikis seseorang terhadap orang lain atau sebaliknya dalam rangka memenuhi kebutuhan diri atau orang lainnya sesuai dengan tuntutan sosial (Hurlock, 2003: 264).

Ada dua faktor yang mempengaruhi perilaku sosial yakni: 1)Faktor Internal, adalah faktor yang terdapat dalam diri anak dan ikut berpengaruh terhadap perkembangan anak

dalam berperilaku, faktor ini meliputi: pengalaman merupakan guru yang paling baik bagi kita, begitu pula dengan

seorang anak mempengaruhi cara perperilaku; dan 2) Faktor Eksternal merupakan segala sesuatu yang ada di luar diri manusia yang dapat mempengaruhi perkembangan kepribadian dan keagamaan seseorang. Faktor ini dapat timbul dari keluarga, sekolah maupun lingkungannya. Pengaruh lingkungan dapat berupa kondisi 
masyarakat yang ada disekitarnya, apabila baik dan stabil maka akan berdampak baik pula terhadap perilaku setiap individu. Begitu pula, apabila kondisinya tidak baik dan tidak stabil maka akan berdampak pada perilaku setiap individu.

\section{METODE}

Pendekatan ini merupakan penelitian deskriptif kualitatif. Peneliti kualitatif adalah peneliti yang bertujuan untuk memahami fenomena yang terjadi pada subjek penelitian, mulai pengumpulan data secara langsung kelokasi untuk memperoleh data yang lebih valid (Melong, 2007:6) pendekatan deskriptif kualitatif digunakan dalam penelitan ini dengan tujuan untuk mendeskripsikan perilaku, peristiwa atau kegiatan di lokasi secara rinci dan mendalam berdasarkan fenomena yang terjadi pada anak-anak Buddhis yang ada di Dusun Lenek.

Pembahasan dalam skripsi ini menggunakan dua jenis data yakni: data primer dan data skunder. Data primer merupakan data yang diperoleh dari lapangan, yakni data yang diperoleh dari informan melalui wawancara sedangkan data skunder merupakan data pendukung yang diperoleh dari jurnal, dokumen, skripsi, dan tulisan ilmiah lainnya.

Instrumen penelitian adalah pedoman tertulis tentang wawancara atau pengamatan, ataupun daftar pertanyaan yang dipersiapkan untuk mendapatkan informasi dari responden (Gulo, 2002:123). Instrumen utama dalam penelitian adalah peneliti itu sendiri yang terjun langsung dalam pengumpulan data.

Informan merupakan seseorang yang diminta informasi terkait objek yang diteliti, yang mempunyai banyak informasi terkait data dari penelitian yang dilakukan. Informan peneliti adalah individu yang berfungsi dalam rumusan masalah penelitian (Moleong, 2006:44). Informan dari penelitian adalah anak-anak Buddhis di Dusun lenek, pendiri kegiatan, orangtua anak-anak yang mengikuti kegiatan.
Untuk memperoleh data di lapangan, penulis mengadakan penelitian menggunakan teknik pengumpulan data sebagai berikut:

a. Observasi yakni metode pengumpulan data yang menggunakan pengamatan secara langsung maupun secara tidak langsung. Metode observasi dalam penelitian ini digunakan untuk mengamati langsung maupun tidak langsung tentang perilaku anak-anak Buddhis yang ada di Dusun Lenek (Riyanto, 2010:98).

b. Wawancara yakni metode pengambilan data dengan cara menanyakan sesuatu kepada seseorang yang menjadi informasi atau responden/informan. Berdasarkan penjelasan tersebut, peneliti akan melakukan wawancara terhadap beberapa informan seperti anak-anak Buddhis yang mengikuti kegiatan Children Dhamma Program (CDP) beserta orangtua mereka (Afifuddin, 2009: 131)

c. Dokumentasi yakni cara mengumpulkan data yang dilakukan dengan menyelidiki benda-benda tertulis dan mencatat hasil temunya. Dokumentasi pada penelitian ini dapat berupa vidio maupun foto-foto, dan jadwal kegiatan Children Dhamma Program (CDP) dari tahun ke tahun.

Teknik analisis data yang digunakan peneliti sebagaimana yang dikemukan Miles Hubberman dan Saldana (2014:31) adalah sebagai berikut:

a. Kondensasi Data (Data Condensation): sebagai proses pemilihan dan memfokuskan pada hal-hal yang penting dengan penyederhanakan serta tranformasi data mentah yang muncul dari catatan tertulis di lapangan. Kondensasi ini dilakukan dengan cara membuat catatan, ringkasan atau mengkode data dan menyisihkan data atau informasi yang tidak relevan.

b. Display Data(Data Display):

merupakan tahap dari teknik analisis data kualitatif. Penyajian data merupakan kegiatan saat sekumpulan data disusun secara sistematis dan mudah dipahami, sehingga memberikan kemungkinan menghasilkan kesimpulan.

c. Verifikasi dan Penarikan Kesimpulan (Conclution Drawing and Verfication): 
akhir dari analisis data dengan penarikan kesimpulan yang menghasilkan hipotesis dan deskripsi atau gambaran objek yang tidak jelas menjadi jelas. Adanya data yang didapatkan melalui wawancara, observasi dan dokumentasi. Maka penelitian ini penarikan kesimpulan.

Untuk memudahkan proses analisis data, maka dilakukan pengkodean (coding) dengan cara membuat kode-kode terhadap hasil wawancara, observasi, serta dokumentasi. Keabsahan data pada penelitian ini, peneliti menggunakan teknik trigulasi data. Trigulasi data adalah analisis jawaban subjek dengan meneliti secara data empiris atau lainnya yang tersedia. Trigulasi dapat dilakukan dengan menggunakan teknik yang berbeda (Nasution, 2003:115). Teknik trigulasi yang digunakan dalam penelitian ini adalah trigulasi sumber data. Trigulasi sumber berarti mengroscek kebenaran data yang diperoleh dari sumber yang berbeda seperti wawancara, dokumentasi dan observasi.

\section{HASIL DAN PEMBAHASAN}

Penelitian ini dilakukan di Dusun Lenek, Ds. Bentek, Kec. Gangga, Kab. Lombok Utara. Tepatnya di Vihara Buddhavamsa. Vihara Buddhavamsa merupakan salah satu vihara yang terletak di Dusun Lenek, Lombok Utara. Vihara ini dibangun pada tahun 2006 di atas tanah dengan luas $5400 \mathrm{~m}^{2}$, vihara ini pula dibangun oleh umat Buddha Theravada Indonesia, sedangkan ketua dari pembangunan ini adalah YM. Sri Subalaratano Mahāthera. Yang ikut membantu pembangunan vihara ini adalah Kalyana Samagi Jakarta. Bangunan yang terdapat di Vihara ini adalah dhammasala, kuti, dapur, ruang makan, dan aula. Vihara Buddhavamsa di bawah binaan Sangha Theravada Indonesia. Vihara ini juga diresmikan pada tahun 2016 yang dihadiri 35 bhikkhu, Samanera, dan Atthasilani.

Vihara Buddhavamisa memiliki jarak $40 \mathrm{~km}$ dari Kota Mataram yakni Ibu Kota Nusa Tenggara Barat. Dibutuhkan waktu kurang lebih dua jam dari Bandara Internasional Lombok Praya untuk sampai di vihara ini. pemandangan yang asri yang berlatar belakang perkampungan dan perbukitan, sedangkan bagian depa berlatar hamparan sawah yang tertata rapi dan ujung depan terdapat sebuah pantai yang berjejeran pohon kepala. Di vihara ini diketuai oleh YM. Bhikkhu Saccadhammo Thera.

Setelah dilakukan penelitian secara langsung ke lapangan, peneliti mengemukakan manfaat dari mengikuti kegiatan Children Dhamma Program (CDP).

a. Kemandirian

Setiap individu yang mandiritidak memerlukan petunjuk yang detail dan terus menerus tentang bagaimana mencapai akhir, ia juga bisa bersandar pada dirinya sendiri bukan keorang lain. Dalam kamus Psikologi kemandirian berasal dari kata "Independence" yang diartikan sebagai suatu kondisi dimana seseorang tidak tergantung dalam menentukan keputusan dan adanya sikap percaya diri Kemandirian (Chaplin, 2011:343).

b. Tanggung Jawab

Bertanggung jawab menurut Pupuh (2013:130), :Biasa menyelesaikan tugastugas tepat waktu, menghindari sikap ingkar janji, dan biasa mengerjakan tugas sampai selesai". Apabila dilihat dari pamaparan tersebut, bertanggung jawa diartikan sebagai perilaku seseorang untuk melaksanakan tugas atau kewajiban yang seharusnya dilakukan, terhadap dirinya sendiri ataupun terhadap orang lain.

c. Kedisiplinan

Menurut Pupuh (2013:108), disiplin adalah "Tindakan yang menunjukkan perilaku tertib dan patut terhadap ketentuan dan peraturan". Dari dari penjabaran arti dari disiplin itu sendiri, anakanak diharapkan dapat mematuhi peraturan yang ada. Apabila dapat mengikuti tata tertib atau peraturan yang ada, anak-anak menjadi terbiasa dengan aturan sehingga akan terbentuk dalam diri anak-anak Buddhis Dusun Lenek, Ds. Bentek, Kec. Gangga, Kab. Lombok Utara.

d. Sabar

Menurut Quraish Shihab dalam (Yusuf, 2018), sabar adalah menahan diri dari suatu 
yang tidak berkenan di hati. Ia juga berarti ketabahan. Selain itu, ia menjelaskan bahwa kesabaran secara umum dibagi menjadi dua: 1) Sabar jasmani, yaitu kesabaran dalam menerima dan melaksanakan perintah-perintah keagamaan yang melibatkan anggota tubuh seperti sabar dalam meelaksanakan pradaksina. 2) sabar rohani menyangkut kemampuan menahan kehendak nafsu yang dapat mengatar kepada kejelekan semisal sabar dalam menahan amarah, atau menahan nafsu seksual yang bukan pada tempatnya. Kesabaran rohani berkaitan dengan pancasila Buddhis yang ketiga, yaitu Kāmesu Micchācāra Veramani Sikkhapadam Samādiyāmi, yang berarti Aku bertekad melatih diri kepada tidak menerapkan perbuatan asusila.

Kegiatan Children Dhamma Program (CDP) memiliki peran dalam membentuk perilaku sosial seperti bentuk pengetahuan, sikap sosial dan sikap spiritual.

Pengetahuan akan suatu objek mengandung dua aspek yaitu aspek positif dan aspek negatif. Kedua aspek ini akan menentukan sikap seseorang, semakin banyak aspek positif dan objek yang diketahui, maka akan menimbulkan sikap semakin positif terhadap objek tertentu (Notoatmojo, 2014).

Suatu pengetahuan tidak didapatkan hanya dari sekolahnya saja, akan tetapi dari luar sekolah juga anak-anak akan mendapatkan pengetahuan seperti dari

kegiatan ini anak-anak akan diajarkan tentang ajaran Sang Buddha, sehingga pengetahuan tentang agama Buddha semakin bertambah.

Kegiatan Children Dhamma Program (CDP) tidak hanya mengajarkan bagaimana cara membentuk karakter anak-anak, tetapi juga kegiatan ini memberikan anak-anak tentang pengatahuan, baik itu tentang ajaran Sang Buddha maupun pengetahuan tentang cara meditasi yang benar seperti apa. Hal demikian dinyatakan oleh Via Sulastri bahwa selama mengikuti kegiatan Children Dhamma Program (CDP), Ia mendapatkan pengetahuan tentang ajaran Sang Buddha ((V.005.W.I-5.4.10). hal tersebut juga dinyatakan oleh Eni bahwa Ia mendapatkan pengetahuan yang berbeda dari sekolah (VI. 006.W.1-6.6.12).

Sedangkan Sikap berawal dari perasaan untuk merespon suatu kejadian atau objek. Sikap dapat merefleksikan sebuah fondasi yang terpenting dan awal dari pemikiran sosial (Ratna Djuwita, 2009:121). Mengenai sikap, sikap memiliki dua aspek yakni sikap sosial dan sikap spiritual.

Silap sosial adalah kesadaran individu yang menentukan perbuatan nyata dan berulan-ulan terhadap objek sosial. Sikap sosial dinyatakan tidak oleh seseorang tetapi diperhatikan oleh orang-orang yang ada disekitarnya (Abu Ahmadi,:152). Sikap sosial tidak dapat dibentuk secara kebetulan, akan tetapi sikap sosial terbentuk karena adanya perangsang oleh lingkungan sosail dan kebudayaan seperti keluarga, sekolah, norma, golongan agama dan adat-istiadat. Untuk membentuk sikap sosial anak-anak dapat dilakukan melalui pembelajaran sosial. Pembelajaran tersebut akan terjadi melalui pembelajaran

a. Classical conditioning yaitu pembelajaran yang dilakukan berulangulang, sama halnya pada saat mengikuti kegiatan Children Dhamma Program (CDP) anak-anak akan diberikan pembelajaran untuk menata sandal, membudayakan antrian secara berulang-ulang.

b. Instrumental conditioning yakni pembelajaran yang mempertahankan pandangan benar. Di kegiatan ini juga mengajarakan anakanak untuk mempertahankan pendangan benar mereka untuk selalu jujur, bersabar, dll.

Kegiatan Children Dhamma Program (CDP) anak-anak juga mendapatkan tentang sikap spiritual, yang dimana dalam hal ini saddha (keyakinan). Saddha merupakan keyakinan yang berdasarkan pengetahuan dari hasil verifikasi atau pemeriksaan atau penyelidik awal beruapa hipotesis terhadap ajaran yang terbentuk karena keterbatasan bukti dan titik awal yang perlu ditindak lanjuti. Kegiatan Children Dhamma Program (CDP) tidak hanya menekankan saddha (keyakinan) namun juga mengajarkan 
moralitas dan melatih samadhi terhadap anakanak Buddhis. Moralitas tidak hanya sebatas penghafalan namun diterapkan secara langsung oleh anak-anak.

Istilah moralitas berasal dari bahasa latin mos (tunggal), mores (jamak) dan kata sifat moralis. Bentuk jamak mores berarti kebiasaan, kelakuan, kesusilaan. Moralitas dalam agama Buddha moralitas adalah sifat moral atau keseluruhan asas dan nilai yang berkenanan dengan baik buruk. Ajaran Buddha moralitas dapat diartikan sebagai sila. Sila dalam agama Buddha ada berapa macam seperti 1. lima sila (Pancasila) untuk perumah tangga, 2. Delapan sila (Atthasila) untuk para Atthasilani atau para umat yang ingin menjalankan, 3. Sepuluh sila (Dasasila) yang dijalankan oleh para Samanera, 4. Dua ratus dua puluh tujuh untuk para Bhikkhu, 5. Tiga ratus sebelas untuk para Bhikkhuni. Sedangkan Samadhi berasal dari bahasa sanskerta, yaitu "sam" yang berati kumpulan, persamaan, gundukan, timbunan, dan "dhi" yang berarti pikiran, ide-ide, datu budhi. Jadi

dapat disimpulkan bahwa Samadhi merupakan kumpulan dari setiap pikiran.

Anak-anak yang mengikuti kegiatan Children Dhamma Program (CDP) melaksanakan delapan sila (Atthasila). Anakanak juga akan melaksanakan puja bakti atau chanting dua kali sehari yaitu pada pagi hari antara pukul 04.30 dan pukul 19.00. Kegiatan Children Dhamma Program (CDP) akan menumbuhkan sikap spiritual anak-anak dari kegiatan-kegiatan yang dilakukan, baik dari meditasi, puja bakti atau chanting, maupun dari proses pembelajaran yang disampaikan oleh para pembimbing seperti Sayadaw U Pandita.

\section{KESIMPULAN}

Kegiatan Children Dhamma Program (CDP) dapat membentuk perilaku sosial anakanak Buddhis di Dusun Lenek. Kegiatan tersebut membuat jadwal yang akan dilakukan setiap harinya, seperti makan, belajar, meditasi, dan bersih-bersih halaman vihara maupun yang ada disekitar vihara. Contoh dalam membentuk perilaku sosial anak-anak dapat dilihat pada saat berbaris dan menunggu giliran untuk memasuki ruang dhammasala, ruang makan dan ruang belajar. Kegiatan tersebut dapat melatih kesabaran pada anakanak, menata sandal dengan rapi juga merupakan contoh sederhana dalam

membentuk perilaku sosial anak-anak.

Anak-anak akan mendapatkan manfaat dari mengikuti kegiatan tersebut berupa (1). Kemandirian: anak-anak dapat mengurus dirinya sendiri tanpa bergantung terhadap orang lain, (2). Tanggung jawab: anak-anak akan memiliki rasa tanggung jawab terhadap dirinya sendiri ataupun terhadap apa yang dilakukan amupun terhadap apa yang diperbuat, (3). Kedisiplinan: dari beberapa informan menjwlaskan bahwa setelah mengikuti kegiatan Children Dhamma Program (CDP) Ia dapat disiplin terhadap waktunya, dan (4). Kesabaran: hal ini dilatih pada saat mengantre untuk giliran memasuki ruang makan maupun ke dhammasala. Pengetahuan serta sikap sosiap dan sikap spiritual juga diperoleh setelah mengikuti kegiatan Children Dhamma Program (CDP).

\section{DAFTAR PUSTAKA}

1. Afifuddin. 2009. Metode Penelitian Kualitatif. Bandung:CV Pustaka Setia.

2. Bambang, Riyanto. 2010. Dasar-dasar Pembelajaran Perusahaan. Yogyakarta: BPFE.

3. Chaplin. 2011. Kamus Lengkap Psikologi (terjemahan Kartini Kartono). Jakarta:PT. Raja Grafindo Persada.

4. Gulo, W. 2003. Metode Penelitian. Jakarta: PT. Grasindo.

5. Miles, M. B., Huberoman, A. M. dan Saldan J. 2014. Qualitative Data Analisis, A Methods Sourcebook, Edition 3. Terj. Tjeptjep Rohindi Rohidi. Jakarta: UI Press.

6. Moleong, Lexy J. 2007. Metodologi Penelitian Kualitatif. Bandung: PT Remaja Rosdakarya.

7. Hurlock, Elizabeth. 2003. Pendidikan dan Perilaku Kesehatan. Jakarta: Rineka Cipta.

8. 2014. Pendidikan dan Perilaku Kesehatan. Jakarta:RinekaCipta.

9. Fathurrohman, Pupuh, dkk. 2013. Perkembangan Pendidikan Karakter. Bandung: PT. RefikaAditama. 